Vol. 5, No. 1, 2019

УДК 338.2:[620.91:622.691](4:477)

https://doi.org/10.23939/shv2019.01.030

\title{
THREATS AND CHALLENGES TO THE VISEGRAD FOUR ENERGY SECURITY IN THE CONTEXT OF THE "NORD STREAM-2" GAS PIPELINE REALIZATION: DETERMINANTS FOR UKRAINE
}

\author{
Olha Ivasechko \\ Lviv Polytechnic National University \\ ivasechko.2011@ukr.net. \\ ORCID 0000-0003-2141-3309 \\ Bohdana Lapiy \\ Lviv Polytechnic National University \\ danalapiy@gmail.com \\ ORCID 0000-0002-3185-4759
}

(стаття надійшла до редколегії-18.03.2019 р., стаття прийнята до друку - 18.04.2019 р.)

(C) Ivasechko O., Lapiy B., 2019

The energy security state of the Visegrad Group member states in the context of the implementation of the "Nord Stream-2" gas pipeline has been analyzed. The Visegrad Four countries positions regarding the realization of the gas project initiated by the Russian Federation have been considered. It has been clarified that the "Nord Stream-2" pipeline construction is a threat to energy security not only for the Visegrad States, but also for the European Union. Ukraine will lose both the revenue from the transit of natural gas and also geopolitical leverage, with the commissioning of this project.

"Nord Stream-2" is a challenge for both the Energy Union and the concept of a single voice in EU energy policy, as it contributes to the split between the Association member states positions.

It has been concluded that "Nord Stream-2" is not only a business project in the reference frame; Russian projects of gas streams have the additional dimensions of corruption, in particular, and of military influence mainly. It completely falls within the polyhebression technology - the multifrontal, multidimensional aggression of the hybrid type carrying out by the Russian Federation against Ukraine and the West, using non-military tools, among other things. The prospect for the Visegrad Group countries energy security is the Polish project "Northern Gate", which provides for the possibility of the withdrawal of Norwegian gas to Central Europe. This project is lobbied by the V4 as it meets the strategic interests of organization and the EU Energy Community, including Ukraine.

Key words: energy security, pipelines, "Nord Stream-2", the Visegrad Four, the EU.

\section{ЗАГРОЗИ ТА ВИКЛИКИ ЕНЕРГЕТИЧНІЙ БЕЗПЕЦІ ВИШЕГРАДСЬКОЇ ЧЕТВІРКИ В КОНТЕКСТІ РЕАЛІЗАЦІЇ ГАЗОПРОВОДУ “ПІВНІЧНИЙ ПОТІК-2”: ДЕТЕРМІНАНТИ ДЛЯ УКРАЇНИ}

\author{
Ольга Івасечко \\ Національний університет "Львівська політехніка" \\ ivasechko.2011@ukr.net \\ ORCID 0000-0003-2141-3309 \\ Богдана Лапій \\ Національний університет "Львівська політехніка" \\ danalapiy@gmail.com \\ ORCID 0000-0002-3185-4759
}

Проаналізовано стан енергетичної безпеки держав - учасниць Вишеградської групи в контексті реалізації газогону “Північний потік-2”. Увагу акцентовано на позиціях держав Вишеградської четвірки щодо імплементації зазначеного газового проекту ініційованого з боку Російської Федерації. 3'ясовано, що будівництво трубопроводу “Північний потік-2" несе загрозу енергетичній безпеці не лише Вишеградській групі держав, Україні, але й 
Європейському Союзу загалом. За умови введення в експлуатацію зазначеного проекту для України це означає не тільки втрату доходу від транзиту блакитного палива, але й геополітичного важеля впливу.

Зроблено висновок про те, що “Північний потік-2” це не тільки бізнес-проект у системі координат; російські проекти газових потоків мають і додаткові виміри, зокрема, корупційний, а головно військовий, який абсолютно вписується в технологію полігібресії Росії - мультифронтальну, багатовимірну агресію гібридного типу, що їі РФ здійснює проти України та Заходу, використовуючи, з-поміж іншого, невійськовий інструментарій.

Ключові слова: енергетична безпека, трубопроводи, “Північний потік-2", Вишеградська четвірка, СС.

The energy security is the key issue of effective activity of the Visegrad Group countries at the EU level today. The energy security issue is an essential component of national security and ranks among the prominent threats of "soft" security. Central Europe suffered significant disruptions in the supply of natural gas from 2006 to 2009, after the energy wars provoked by the Russian Federation. Thus, the Visegrad countries made a common position on the diversification of energy supplies sources. The key areas of the energy sector cooperation of V4 format in the Central European region were outlined in the Declaration adopted at the V4+ Energy Security Summit in Budapest on February 2010.

The Russian-Ukrainian conflict has also made the significant adjustments to the European energy policy and EU energy security system. The annexation of Crimea, Donetsk and Luhansk regions by the Russian Federation in 2014 raised concerns about further transit violations in the rest of Ukraine and the region of Central Europe.

The gas stress test in 2014, which the EU member states, including the countries of the Central European region had underwent, caused to the following actions: reducing of the import of Russian gas, and the cease of the supply of Russian gas through Ukraine. The point is that V4 countries are poorly integrated into the EU single energy market; they are mostly guided by national interests. Therefore the common goal for the Czech Republic, Slovakia, Hungary and Poland is to integrate within the North-South Corridor as a bloc, in order to connect with alternative, non-Russian sources.

The Visegrad platform member states are known not only for common historical and cultural roots, but also for number of threats including transit, diversification and change in the delivery of hydrocarbons [Dinsdale \& Laco 2009].

The initiatives launched in Europe to diversify and reduce Russian gas in the Community energy sector have forced Russia to respond to challenges in a different way including gas discounts for some countries, temporary reductions in gas exports to Poland in 2014 and, eventually, a significant reduction of gas flows through Ukraine from 2019 when the contract for transit is completed, and "Nord Stream-2" is involved.

The relations between the Visegrad states and Ukraine are politically and economically important not only due to their proximity; close economic and cultural ties, but also, in the context of our country energy sector stability.

The Ukraine-2020 Sustainable Development Strategy and the Energy Strategy 2035 indicate the need to integrate Ukraine's energy systems into the European Network of Gas Transmission System Operators (ENTSOG), which includes our closest neighbors of the V4 countries. In 2015, President Petro Poroshenko mentioned the EU countries that helped to provide Ukraine's energy security through reverse supplies of natural gas. Such countries as Poland, Slovakia and Hungary were among these partners [Максак 2018].

The hybrid war held by Russia in Ukraine has led to many challenges in the energy policy of the Visegrad countries. Taking into account official Moscow is trying to divide the European Union and especially V4 member states, the Visegrad Group governance and experts have to form a strategic vision of regional energy security. The V4 participating countries should create mechanisms and so-called "action plans" that would allow joint and quick response to the challenges of energy security in the region. It requires coordination of efforts in the energy security interests. We consider it would be advisable for the alliance to play a key role in addressing regional crisises, especially concerning the energy dimension of the Ukrainian conflict.

Given to the energy security geopolitical, region challenges and the Visegrad countries stability, it is extremely important to create an extra power in the alliance of energy policy and diplomacy. Therefore, the Visegrad Group energy security issue is highly relevant in the context of Russia's hybrid war against Ukraine and the challenges it faces.

The purpose of this article is to identify the threats and challenges of the North Stream-2 i building for the Visegrad Four countries energy security and factors for Ukraine.

The study of the modern threats and challenges specific to the V4 energy security has become widespread in the context of the implementation of the "Nord Stream-2", especially in Western (European and American) academic environments. Such researchers as Taisen, Slobodian, Goda, Dinsdale and Laco [Slobodian \&Theisen 2016: 24; Dinsdale \& Laco 2009], focused on different problematic aspects of the V4 member states energy sector. There is also a considerable scientific interest in studying the Visegrad Group energy threats in the context of the "Nord Stream-2" implementation. In 
particular, there are such scholars of Ukrainian political science as Maksak Genadiy, Mudriyevskaya Irina, Gonchar Mikhail and Prokopchuk Stanislav [Максак 2018; Мудрієвська 2016: 65-72; Burgomistrenko \& Gonchar 2018: 5; Прокопчук 2017]. They emphasized the Visegrad countries energy potential as well as the "Nord Stream-2" implementation energy threats. At the same time, there are no coherent researches in Ukraine studying modern threats in the Visegrad Group countries energy sector in the context of the "Nord Stream-2" implementation. Such study is essential for our country, because of the priority nature of interaction with the European Union.

The Central Europe region has a key strategic importance for the natural gas supply, due to its location in the East-West and North-South transport links. This region can both achieve a significant independence from suppliers of one source, and become an important player in the European energy market. It should be emphasized that both Ukraine and V4 countries are dependent on the gas import, mainly from the Russian Federation. According to the information sheet of the CEE region in 2014, the share of Russian gas in the Visegrad countries is: the Czech Republic - 64,4\%, Hungary - $100 \%$, Poland - $84 \%$, Slovakia - $100 \%$ [Мудрієвська 2016: 65-72; "Beyond gas" - energy security issues in the V4 after 2020, 2018: 24].

Today, the key task for Ukraine and the Visegrad countries energy sector is to create a regional gas hub in the CEE region. The ministers of Energy and Economy of the V4 member states signed the Memorandum of Understanding on gas market integration in the V4 region, as far back as October 31, 2012. As early as July 16, 2013, the RoadMap towards the regional gas market among Visegrad 4 countries, with fixed provisions on readiness of cooperation with Ukraine, was concluded [Мудрієвська 2016: 65-72].

At the same time, the important point of the cooperation between Ukraine and Visegrad Group in the energy sector is Slovakia's presidency in V4 from mid2018. We think, it is advisable to draw attention to two important points in this context, distinguished by leading experts. Point one, the fact that the official Bratislava is the most optimistic about the perception of V4 as an influential player in the EU. Point two, Slovak side in the relations with Ukraine is lobbying for energy security and energy efficiency, which is an area of interest for official Kyiv today [Максак 2018a].

At present, significant differences are observed in the area of national energy security, supply or energy carries routes and integration of energy markets in the Visegrad countries (Poland, Czech Republic, Slovakia, and Hungary). The Czech Republic and now Poland are much more diversified due to the supply of liquefied natural gas through a LNG terminal than Slovakia and
Hungary. The point is that Hungary and Slovakia are largely energy dependent on one supplier (Russia) in the gas sector in their energy balance, as the terms of their long-term contracts have not been reviewed, but the leadership of both countries intends to ensure diversification of sources in the near future.

Focusing on the gas supply, it should be noted the purpose of the Visegrad Group energy policy is diversification of supply sources, suppliers and transit routes, mainly, as well as construction of a new gas corridor.

In June 2013, the Trans-Atlantic Pipeline (TAP), the Southern Corridor of the EU opening the fourth route to Europe was chosen. This means for the first time the EU have access to import from the Caspian basin. The second phase of the Shah Deniz field in Azerbaijan should produce not less than 16 billion cubic meters per year starting from 2018. The gas will be transported through existing pipelines from Azerbaijan to Turkey, which has intended to consume 6 billion cubic meters per year. The remaining 10 billion cubic meters will be supplied further West: through the Trans-Anatolian gas pipeline (TANAP) to the Turkish-Greek border and via the TAP to the Italian coast. The key reasons for choosing the gas pipeline TAP were economically justified. TAP is the shortest and cheapest way to supply gas to Europe, which is $459 \mathrm{~km}$ shorter and \$500 million cheaper than the USA Nabucco gas pipeline [Slobodian \&Theisen 2016: 22].

The TAP pipeline will outbid Nabucco-West, with or without the Visegrad group. Nevertheless, the new situation in the European energy market opens up new opportunities for the Visegrad Group. Firstly, Caspian gas can be transported to the V4 countries through the TAP gas pipeline. Taking into account the initial capacity of TAP (10 billion cubic meters / per year, i.e. $2 \%$ of EU consumption), its immediate value, obviously, is negligible. Despite this, the capacity of the TAP can be increased to 20 billion cubic meters. If demand for gas in Central Europe is sufficient, gas can pass through Bulgaria and Romania to Hungary because of the constructed or designed interconnects. Secondly, it can be concluded that TANAP is the so-called "new Nabucco", since it copies the initial route Nabucco through the territory of Turkey. In order to strengthen its energy security, the Visegrad Group and Ukraine may need to consider the problem of pipelines in a broader perspective [Slobodian \& Theisen 2016: 24].

The "Nord Stream-2" is next gas pipeline, the project of the Russian Federation, which is currently considered by the EU Member States as one of the options for the supply. The target markets for the "Nord Stream-2" project are Germany, France, Austria and Italy. Poland, the Baltic States, Ukraine, Moldova, Slovakia, the USA and Denmark opposed the 
construction of the gas pipeline [“ЗЗгодом - Балтика, a потім Польща": у Міноборони країни закликають Європу не підігрувати Путіну 2019]. "Nord Stream-2" is the main gas pipeline from Russia to Germany, which should be laid through the Baltic Sea bypassing Ukraine. Germany, Finland, and Sweden issued all permits for the construction and operation of the gas pipeline. According to Donald Tusk, chairman of the Council of Europe, "Nord Stream-2" will increase Europe's dependence on one supplier of natural gas and concentrate $80 \%$ of Russian gas import on a single route. Also, the issue of energy security in the EU, the region of Central and Eastern Europe, has also risen at the Munich Security Conference, which took place on February 15-17, 2019. In particular, Polish Minister of National Defense Mariusz Błaszczak during the conference emphasized the threat to the energy security of the EU, posed by implementation of the "Nord Stream-2", noting that the funds that official Moscow would receive from the sale of gas would be spent on arms. Therefore he considered it paradoxical, if Russia was armed with money from Western partners, and the EU member states in search of a response to Russian arms, would strengthen cooperation within the Alliance of NATO [“Згодом Балтика, а потім Польща": у Міноборони країни закликають Європу не підігрувати Путіну 2019].

The official position of the Czech Republic regarding the implementation of the "Nord Stream-2" pipeline was clearly highlighted by the representative of the Prague think tank "European Values" Yakub Yando, who noted that country generally supports this gas project of the Russian Federation, regardless of criticism of the Allies in the region [Среміца 2018].

Experts point out that some EU member states do not consider this cooperation as a real threat. However, the increase of the purchased energy amount and infusion of money into Russian economy make the Russian Federation more dangerous for Europe, carrying out cyber-attacks, bribery of politicians, parties, media, journalists, deputies. In this way, Russia deepens political risks and crises in Western Europe. At the same time experts point out, Russia's aggressive actions make Europeans invest in military rearmament, increasing defense spending [Среміца 2018]. As analysts stress: "this dubious cooperation, which brings a special profit for a relatively small proportion of European businessmen and corruption of officials, leads to global instability in Europe" [Среміца 2018].

On the other hand, Slovakia is in solidarity with Ukraine regarding the construction of the "Nord Stream-2", as the leaders of both countries have coordinated efforts to prevent the construction of this gas pipeline [Президент Словаччини про “Північний потік - 2": Це виключно політичний проект].
Focusing on the position of Hungary, it should be noted that the Prime Minister Viktor Orban emphasized that Russia's gas monopoly era in Hungary is ending, as a contract for the supply of natural gas from Romania for the period of 15 years had been signed. He noted that three Hungarian firms won a tender in Romania. Hungary will buy 4 billion cubic of natural gas from Romania per year, equal to half the volumes of each year gas consumption. The Hungarian prime minister believes that the supply of natural gas from Romania will start after 2022. Such an official statement by Viktor Orban on the supply of Romanian gas corresponds to the position of the United States and the European Parliament on the need to reduce the EU's dependence on Russian gas [Кухалейшвілі 2018].

Ukrainian scholar, Mikhail Honchar, President of the Center for Global Studies, Strategy XXI, points out that the construction of "Nord Stream-2" in the Baltic and the Turkish Stream in the Black Sea will be used by the Russian Federation to increase and diversify its military presence in the waters of both seas and the coast. Consequently, the likelihood of the scenario of hybrid occupation of the Baltic States and the expansion of the force grouping in the Kaliningrad region, under the pretext of establishing a security zone for greater securitization of the main Russian-EU gas trade route and Russia-Germany, is increasing sharply. It is anticipated that such NATO member states, as Germany, Turkey, and Bulgaria, have an opposite to the Alliance view.

In essence, the gas pipeline corridor is a lengthy platform on which Russia can hide additional mobile intelligence capabilities to scan underwater and surface environment along the entire coast of NATO [Burgomistrenko \& Gonchar 2018: 5].

Specialists in the field of energy today are focusing on the Northern Gate the Polish project which allows the withdrawal of Norwegian gas to Central Europe. This project is lobbied on the level of V4, and most of all Slovakia. With this in mind, the Northern Gate can become the second key element of the NorthSouth gas corridor, along with the LNG terminal in Swinoujscie. The implementation of the Northern Gate and North-South Gas Corridor projects is of the national interest of Ukraine, given the powerful Ukrainian GTS with its unique network of underground gas storage facilities in the western part of the country. The result of the implementation of these projects may be the process of greater integration of gas markets in Central and Eastern Europe and the creation of a gas hub for the states of the Visegrad Four and the Baltic [Прокопчук 2017].

Another promising source of gas for the states of the Visegrad Group is gas transportation from the Norwegian continental shelf through the proposed 
project "Baltic Pipe" between Denmark and Poland, with a capacity of up to 10 billion cubic meters per year. However, it should be noted that this is a purely technical proximity.

Today, the V4 countries have a low level of supply of Norwegian gas, most of it is bought by the Czech Republic, and it accounts only a third of import from Norway. The country, however, depends on the physical flows of gas from Russia. Although the European Union is interested in Norway remaining an integral supplier of gas to Europe, the trend of low demand and lowering prices makes the investment in new projects more risky for public campaigns. If these circumstances were dealt with access to a new natural gas source would be possible and, consequently, the change in the V4 market game rules will provide physical diversification for the CEE region [Slobodian 2016].

The North-South Gas Corridor has the form of a triangle with LNG (liquefied natural gas) - terminals at each end and the Nabucco gas pipeline in the middle, with well-interconnected systems in the region. The cooperation of the Visegrad Group with regard to the North-South Gas Corridor has recently been expanded in the framework of the $\mathrm{V} 4+$, with the indispensable participation of Croatia and Romania.

In terms of domestic national networks, the corridor is divided into the following projects: Interconnector Poland-Slovakia, Interconnector Czech Republic- Poland, Reverse Corridor Czech RepublicSlovakia, Interconnector Hungary-Slovakia, and Croatia-Hungary.

The cooperation between CEE countries and Ukraine is possible. Adding a fourth angle to the aforementioned triangle on the eastern border, namely Ukraine, can increase the number of mutual benefits for the V4 and Ukraine as follows:

(1) Connecting existing pipelines and planned interconnectors to the western part of the Ukrainian GTS and incorporating Ukrainian GHG into the North-South gas corridor will automatically reduce the need to build additional adjacent pipelines in the CEE. (2) Establishing a gas hub on the EU's eastern border. (3) Developing a common policy for the required investment in infrastructure and the search for new sources of supply [Дік 2013: 46].

Experts point out that the implementation of the "Nord Stream-2" gas project, poses a threat to energy security not only for Ukraine, but also for the member states of the Visegrad Four, as well as for the Baltic States. Today, despite the resistance of V4, Gazprom is struggling to persuade the official Bratislava, keeping transit of gas through the Slovak gas transit system, to use the scheme for the transportation of Russian gas from the second thread of the future of the "Turkish Stream" via the route Eastring, developed by the Slovak company Eustream.

Due to the joint efforts of the Visegrad countries and the principle position of the Polish company PGNiG the gas pipeline "Nord Stream-2" has not been given support in the EU yet. Thus the refusal from "Nord Stream-2" is extremely important for Europe, and its blocking by the USA is really meaningful.

According to these facts, one may conclude that "Nord Stream-2" is not only a business project in the reference frame; Russian projects of gas streams have the additional dimensions of corruption, in particular, and of military influence mainly. It completely falls within the polyhebression technology - the multifrontal, multidimensional aggression of the hybrid type carrying out by the Russian Federation against Ukraine and the West, using non-military tools, among other things.

Today, it would be advisable to support Northern Gate and North-South Gas Corridor at the level of the Visegrad Four and at the EU level since these projects are in the line with the strategic interests of the V4 and the Energy Community of the EU. The official Kyiv should also take a more distinct position regarding the support at all levels of such a strategic approach to strengthen Ukraine's energy independence with the assistance of the European partners. The prospect of the further research can be a scientific investigation on the regulatory legal regulation of the energy policy of the participating states within the EU.

\section{ЛІТЕРАТУРА}

Дік, А. (2013). Енергетична безпека в Центральній та Східній Європі: в пошуках єдиного підходу. Central European Policy Institute, EUROPEUM Institute for European Policy, Hungarian Institute of International Affairs, Iнституm економічних досліджень та політичних консультацій: 3вim. Київ. Отримано 3 https://think.visegradfund.org/ brussels-office/

Єреміца, В. (2018). “Північний потік-2”: дипломатія за і проти. Радіо Свобода. Отримано 3 https://www. radiosvoboda.org/a/29087344.html

“Згодом - Балтика, а потім Польща": у Міноборони країни закликають Європу не підігрувати Путіну. (2019). Uazmi. Отримано 3 https://uazmi.org/news/ post/gcQipUSYs53feMKi2hnzzg

Кухалейшвілі, Г. (2018). Газова інтрига Орбана: Як Угорщина грає на суперечностях Росії і США. 112. иа. Отримано з https://ua.112.ua/statji/hazova-intryha-orbana-yakuhorshchyna-hraie-na-superechnostiakh-rosii-i-ssha432770.html

Максак, Г. (2018b). Як далі будувати співпрацю України з країнами Вишеградської групи. Українська призма: рада зовнішньої політики. Отримано $3 \mathrm{http} / /$ webcache. googleusercontent.com/search?q=cache:dSHvHEaMGkQJ: prismua.org/ ua/\%25D1\%258F\%25D0\%25BA-\%2

Максак, Г. (2018а). Співробітництво в сфері безпеки V4 + Україна: межі можливого. Українська призма: Рада зовнішньої політики. Отримано 3: http://prismua.org/ v4ukraine-security-cooperation-limits-possible-ukrainianperspective/ 
Мудрієвська, I. (2016). Стан і перспективи співробітництва України з країнами Вишеградської групи в енергетичній сфері. Емінак. № 2(3), 65-72. - Отримано 3 http://nbuv.gov.ua/UJRN/eminak_2016_2\%283\%29_13

Президент Словаччини про “Північний потік-2": Це виключно політичний проект (23 листопада, 2018). Gordon.иа. Отримано 3 https:/gordonua.com/ukr/news/ politics/-prezident-slovachchini-pro-pivnichnomu-pototsi-2-tsevikljuchno-politichnij-proekt-528176.html

Прокопчук, С. (2017). Енергетична безпека - виклик для України. Ось де бомба сповільненої дії! УКРІНФОРМ. Отримано 3 https://www.ukrinform.ua/rubric-economy/ 2175992-energeticna-bezpeka-viklik-dla-ukraini.html

"Beyond gas" - energy security issues in the V4 after 2020. (October, 2018). Final Synthesis Report. Отримано 3 http://webcache.googleusercontent.com/search?q=cache:XrH61 apPEGEJ:www.amo.cz/wp-content/uploads/2018/12/V4-BeyondGas-Beyond-2020-Final-Synthesis-Report.pdf $+\& c d=1 \&$ hl $=$ $\mathrm{uk} \& \mathrm{ct}=\mathrm{clnk} \& \mathrm{gl}=\mathrm{ua}$

Burgomistrenko, A. \& Gonchar, M. (October, 2018). Offshore gas infrastructure in the Russian counteraction to NATO on the eastern flank: potential for a hybrid use in the Black and Baltic seas. Centre for Global Studies 'Strategy XXI'. Kуiv. Отримано з https://ukraine-office.eu/offshore-gasinfrastructure-in-the-russian-counteraction-to-nato-on-the-eastflank-potential-for-a-hybrid-use-in-the-black-and-baltic-seas/

Dinsdale, C. \& Laco, P. (December, 2009). How the V4 can cooperate to overcome energy challenges. Slovak Spectator. Отримано 3 https://spectator.sme.sk/c/20034723/ how-the-v4-can-cooperate-to-overcome-energy-challenges.html

Slobodian, N. (November, 2016). A direct access of a new source of gas would be a game-changer on the V4 markets. Visegrad insight. Отримано 3 http://visegradinsight.eu/energysecurity-in-v4/

Slobodian, N. \& Theisen, N. (2016). Single gas market and energy security in the Visegrad states: models, challenges and perspectives. Report The National Centre for Strategic Studies. Warsaw. Отримано 3 http://webcache.googleusercontent. com/search?q=cache:4qcVx1-_8cAJ

\section{REFERENCES}

"Beyond gas" - energy security issues in the V4 after 2020. (October, 2018). Final Synthesis Report. 101 p. Retrieved from http://webcache.googleusercontent.com/search?q=cache: XrH61apPEGEJ:www.amo.cz/wp-

content/uploads/2018/12/V4-Beyond-Gas-Beyond-2020-FinalSynthesis-Report.pdf $+\& c d=1 \&$ hl=uk\&ct $=$ clnk $\& g l=u a$

Burgomistrenko, A. \& Gonchar, M. (October, 2018). Offshore gas infrastructure in the Russian counteraction to NATO on the eastern flank: potential for a hybrid use in the Black and Baltic seas. [In Ukrainian]. Centre for Global Studies 'Strategy XXI'. 24. Kyiv. Retrieved from: https://ukraineoffice.eu/offshore-gas-infrastructure-in-the-russiancounteraction-to-nato-on-the-east-flank-potential-for-a-hybriduse-in-the-black-and-baltic-seas/
Dick, A. (2013). Energy Security in Central and Eastern Europe: A Unified Approach. [In Ukrainian]. Institute for Economic Research and Policy Consulting: Report. Retrieved from https://think.visegradfund.org/brussels-office/

Dinsdale, C. \& Laco, P. (December, 2009). How the V4 can cooperate to overcome energy challenges. Slovak Spectator. Retrieved from https://spectator.sme.sk/c/ 20034723/ how-the-v4-can-cooperate-to-overcome-energy-challenges.html

Kuhaleishvili, G. (2018). Orban Gas intrigue: How Hungary plays in contradictions between Russia and the US. 112.ua. Retrieved from https://ua.112.ua/statji/hazova-intryhaorbana-yak-uhorshchyna-hraie-na-superechnostiakh-rosii-issha-432770.html

Maksak, G. (2018a). Security cooperation V4 + Ukraine: the boundaries of possible. [In Ukrainian]. Ukrainian prism: Foreign Policy Council. Retrieved from http://prismua.org/v4ukraine-security-cooperation-limitspossible-ukrainian-perspective/

Maksak, G. (2018b). How to Further Build Ukraine's Cooperation with the Visegrad Countries. [In Ukrainian]. Ukrainian prism: foreign policy council. Retrieved from http://webcache. googleusercontent.com/search?q=cache:dSHv HEaMGkQJ:prismua.org/ua/\%25D1\%258F\%25D0\%25BA-\%2

Mudriyevska, I. (2016). State and prospects of Ukraine cooperation with the countries of the Visegrad Group in the energy sector. [in Ukrainian]. Eminak, № 2(3), 65-72. Retrieved from http://bnbuv.gov.ua/UJRN/ eminak_2016_2\% $283 \% 29 \_13$, s. 28

Prokopchuk, S. (2017). Energy security is a challenge for Ukraine. That is where the bomb of the slow action is! [In Ukrainian]. UKRINFORM. Retrieved from https://www. ukrinform.ua/rubric-economy/2175992-energeticna-bezpekaviklik-dla-ukraini.html

Slobodian, N. \& Theisen, N. (2016). Single gas market and energy security in the Visegrad states: models, challenges and perspectives. [In Ukrainian]. Report The National Centre for Strategic Studies 46. Warsaw. Retrieved from http://webcache. googleusercontent.com/search?q=cache:4qcVx1-_8cAJ

Slobodian, N. (November, 2016). A direct access of a new source of gas would be a game-changer on the V4 markets. Visegrad insight. Retrieved from: http://visegradinsight. eu/energy-security-in-v4/

Slovak President on "North Stream-2": This is an exclusively political (23 lystopada, 2018). [In Ukrainian]. Gordon.ua. Retrieved from: https://gordonua.com/ukr/news/ politics/-prezident-slovachchini-pro-pivnichnomu-pototsi-2-tsevikljuchno-politichnij-proekt-528176.html

"Subsequently - Baltika, and then Poland" the Ministry of Defense calls on Europe not to support Putin. (2019). [In Ukrainian]. Uazmi. Retrived from https://uazmi.org/news/post/ gcQipUSYs53feMKi2hnzzg

Yeremica, V. (2018). "North-Stream 2": Diplomacy for and against. [In Ukrainian]. Radio Svoboda. Retrieved from: https://www.radiosvoboda.org/a/29087344.html 